\title{
Women's Role in Raising Awareness of Rumours during the COVID-19 Crisis in Saudi Society
}

\section{Loulouh Brikan Albrkan, Hend Faye AL-shahrani*}

Section: Healthcare

ISI Impact Factor

(2019-20): 1.628

IC Value (2019): 90.81

Social Planning department, Faculty of Social Services, Princess Nourah bint Abdulrahman University, Saudi Arabia.

SJIF $(2020)=7.893$

(c) (i) (8)

Copyright@IJCRR

\section{ABSTRACT}

Introduction: Rumours are the critical method of intimidating individuals and psychosocial communities, as they are not limited to a particular time or place; yet, human society exists, the threat of rumour has emerged, especially in crises. Unfortunately, the Coronavirus crisis (COVID-19) epidemic has been accompanied by many rumours and deceptive news, affecting psychological and social stability within the family and society. Accordingly, Mothers bear a large part in building families, which is the basic unit of community. For instance, raise awareness among family members about rumours and their risk to their psychological and social security and society as a whole.

Objective: We aimed at identifying Saudi women's role in raising awareness of rumours during the COVID-19 crisis within the family and society. Besides, suggest proposals and mechanisms activate Saudi women's role in raising awareness to reduce rumours.

Methods: The study has relied on the descriptive approach. A questionnaire to determine Saudi women's role was applied to a sample of 416 Saudi women in Riyadh, Saudi Arabia.

Results: As a result of this study, Saudi women play a significant role in raising awareness to reduce rumours during the COVID-19 crisis within the family and society.

Conclusion: The study recommended organizing lectures, seminars, and meetings to educate women and the family about the dangers of rumour and its spread. Hence, examine and improve family conditions by national authorities, to create a risk-conscious environment. Further, informed socialization of children against rumours. In addition, launch a national initiative to raise awareness of rumours. Thus, establish an integrated information Centre to provide information and reduce rumours. School curricula should also be taken into account to incorporate the dangers of rumours and their impact on the individual and society..

Key Words: Women's Role, Awareness, Rumours, Coronavirus Disease (COVID-19), Saudi Society

\section{INTRODUCTION}

In late 2019, a new coronary virus, COVID-19, emerged in China, and within three months, the virus spread across the world rapidly, as it is highly contagious and there is no known vaccine or specific treatment. ${ }^{1,2}$ Therefore, the World Health Organization (WHO) had to declare it a global pandemic, as well as many precautionary and extraordinary measures have been taken by the Governments of the world to address the epidemic and curb its spread within the States. ${ }^{3}$ On January 30, 2020, WHO declared health emergency status. As a result of the rapid spread of the Coronavirus epidemic, COVID-19 and, on March 11, 2020, announced the new Coronavirus, COVID-19, as a global epidemic. As a result of the high incidence and the prevalence worldwide., ${ }^{4,5}$ All people worldwide panic in different behaviours, which has had a significant impact on the social, economic, and psychological aspects of the world. ${ }^{6}$ Notwithstanding, whether a person is infected or has direct contact with an infected person or is distant from infection locations. ${ }^{7}$

Saudi Arabia is considered one of the first countries to seek bold and early precautionary measures to prevent the spread of the Coronavirus among society members and support the efforts of States and international organizations to confront this pandemic. ${ }^{8}$ Further, the new Coronavirus outbreak, COVID- 19, has led to a massive global crisis, with fear and anxiety among people caused by uncertainty and rapid

\section{Corresponding Author:}

Hend Faye AL-shahrani, Faculty of Social Services, Princess Nourah bintA bdulrahman University, Al Riyadh, Saudi Arabia. Phone: 00966555204862; E-mail: hfalshahrani@pnu.edu.sa

ISSN: 2231-2196 (Print)

Received: 14.04 .2021
ISSN: 0975-5241 (Online)

Revised: 03.05 .2021
Accepted: 23.05 .2021
Published: 11.06 .2021 
spread of the disease with no effective treatment. Additionally, States such as closures and quarantine are taken precautionary measures, creating fertile ground for spreading rumours across all societies. ${ }^{9}$ The lack of appropriate messages and information in a new outbreak also leads to panic and anxiety, with more devastating severe effects on livelihoods, societies' social fabric, the economic landscape, and political stability. Besides, There were significantly high levels of panic, which was accompanied by an expeditious rise in people's fear and anxiety. ${ }^{7}$ Then it could lead to many social problems like isolation, moving away from family members, socializing with friends, changing lifestyle. ${ }^{10}$ Moreover, the spread of misinformation through social media aims to spread terror and fear among people; as well, some disseminate rumours to disturb security at home and perplex social. ${ }^{11}$

The rumour has a profound impact on the individual and society, as it hampers the process of understanding by communities of the conditions they are going through also, it leaves them unable to absorb the imperatives that affect the direction of their movement growth on the ground. Likewise, rumours are breaking communities, deepens and expands the crisis promptly. ${ }^{12}$ Rumours are considered anonymous, rapidly spreading the news, containing part of the truth, which forms the core of its construction and spread. ${ }^{13}$ Rumours of challenges facing humanity, such as the Coronavirus pandemic 2019, swell within weeks of the virus's emergence in China. ${ }^{14}$ More specifically, deceptive rumours and conspiracy theories have globally spread about its origin, combined with tension, leading to increased storage and purchases of goods and face masks. The abundance of information, including misinformation, has been closely linked to the twenty-firstcentury communication system and social media. ${ }^{15}$ Hence, The oversight role of the security and government agencies must be activated in the follow-up on social media; to reduce the spread of rumours among members of Saudi society, and to raise awareness of the dangers of rumours that pose a new security threat to Saudi society. ${ }^{7}$ Misleading information via social media leads to many mental health problems, such as social isolation, bad individual relationships. ${ }^{16}$ family problems, post-traumatic stress disorder, and panic. ${ }^{17}$ depression, social isolation, and anxiety. ${ }^{18}$ Also, behavioural disorders and strain. ${ }^{3}$ Therefore, public health measures must reduce the spread of the COVID-19 pandemic and clarify misinformation spread through social media. We need to respond promptly to minimize the adverse effects on individuals and society. ${ }^{19}$ Additionally, expose rumours and public perceptions, attitudes, and behaviours about COVID-19 discussed through social media. ${ }^{20,21}$ Therefore, it is essential to start with the family through women in society as an educator and an influential factor in the socialization process, to protect her family members from rumours.

Women are responsible for their duties to husband and children in the family during the socialization process. As a re- sult, they have multiple roles in society, such as inculcating behaviours, religious and social values, and guiding children. ${ }^{22-24}$ They also contribute to raising the family's awareness of society's values, norms, and culture, distinguishing between right or wrong, whether it is behaviours, information, or rumours. ${ }^{25}$ Besides, they contribute to raising the awareness of her family members about the gravity of negative behaviour and misinformation about the positive effects that some of her children's peers may have on some alcohol or drugs. ${ }^{26}$ Further, they contribute to raising awareness about the risks and downsides of certain information that is generally shared through social media sites. ${ }^{27}$

This study is based on role theory, whose Founders are Ralph Linton in sociology and George Herbert Mead in social psychology; it refers to cultural norms relating to the psychological and interactive aspects of society members, such as mothers, fathers, sons, daughters, and grandparents. ${ }^{28}$ Additionally, the role refers to family roles' expectations and social texts - how roles are shaped by society's cultural traditions and collective ideologies. More specifically, one aspect of role theory studies how to learn roles during the process of social interaction, i.e., people interact with others, see themselves and others as occupants of particular situations, and learn clues to work. In other words, specific social texts or expectations are linked to certain roles. ${ }^{29}$ Women play several roles at the family and community levels. For example, they may be wives, mothers, relatives, employees, friends of different individuals, and members of a social institution..$^{30,31}$ To raise awareness for the people of society.

This study's importance has been highlighted because it focuses on women's role, who plays a significant part in the upbringing process in the family and other parts of society. Also, through her work, mainly if she contributes to the educational process through her career as a teacher for the younger generations to prevent danger and her contribution to avoiding misleading information that adversely affects family members and society. Thus, their contribution to raising awareness of the dangers of rumours during the Corona crisis. Therefore, women need to play their part in raising awareness to reduce rumours during the problem of COVID-19 pandemic.

\section{Research Questions}

- What is the role of women with family in raising awareness to reduce rumours during the COVID- 19 crisis?

- What is women's role in raising awareness to reduce rumours during COVID- 19crisis?

- What are the proposals and mechanisms to activate women's role in raising awareness to reduce rumours during COVID- 19 crisis? 


\section{MATERIALS AND METHODS}

\section{Study design and participants}

The quantitative research methodology was used for this study. This study was applied after the closure in the Kingdom of Saudi Arabia in December 2020. The institutional ethical committee clearance was obtained from the Deanship of Scientific Research at Princess Noura Bint Abdul Rahman University in Riyadh, Saudi Arabia. The authors expected to receive 460 responses within six days, but only 436 questionnaires were returned. Twenty of them were excluded for not following the survey instructions. Thus, the study sample was 416 women, aged 40-60 $(\mathrm{M} \pm \mathrm{SD} 46.12 \pm 1.52)$. The sample was selected through the snowball sampling technique to provide an equal and independent opportunity for selection for the sample. All of the participants live in the city of Riyadh, the sample consisted of mothers of students at Princess Noura Bint Abdul Rahman University. All participants completed the voluntary consent section of the questionnaire and confidentiality was confirmed. Complete the survey on social media sites such as WhatsApp.

\section{Data collection tool and technique}

To collect data, a questionnaire was developed by researchers through a review of previous literature and studies on the role of women in raising awareness of rumours during crises. The questionnaire consisted of two parts. Part I includes demographic data for the sample study. Part II covers the three dimensions of the study. The first dimension is women's role in raising awareness to reduce rumours during the Coronavirus pandemic crisis and consists of 16 items.
The second dimension is women's role in raising awareness to minimize rumours during the new Coronavirus pandemic, COVID- 19, and consists of (9) items. The third dimension is proposals and mechanisms to activate women's role in raising awareness to reduce rumours during the crisis of the new Coronavirus pandemic, COVID- 19, and consists of 12 items. The three-point Likert scale was used (yes, somewhat, no). Content Validity Ratio (CVR) and Content Validity Index (CVI) measurements were also used in the quantitative method. The Cronbach Alpha values were calculated for the three dimensions and were $0.811,0.787$, and 0.897 , and the scale as a whole was 0.899 .

We applied descriptive statistics to analyze the data, including average, standard deviation and percentage. Participants' responses to the dimensions of the questionnaire were analyzed by frequency, percentage, average, and standard deviation. It was analyzed using SPSS 21.

\section{RESULTS}

To answer the first question, what is the role of women with the family in raising awareness to reduce rumours during the crisis of COVID-19pandemic? Iterations, percentages, means, standard deviations, and ranks of sample responses were calculated on the first dimension items: the role of women with families in raising awareness to reduce rumours during the crisis of COVID-19, table 1 shows these results:

Based on the above table, the sample of female students' mothers at Princess Nora University approved the roles offered to women with the family in raising awareness to

Table 1: Means, Standard Deviations, Percentage and ranking on the Dimensions of the first field (Role of Women with Family in Raising Awareness to Reduce Rumours During the Crisis of COVID- 19)

\begin{tabular}{|c|c|c|c|c|c|c|c|c|}
\hline $\begin{array}{l}\text { Sr. } \\
\text { No }\end{array}$ & Items & & Yes & Somewhat & No & $\mathbf{M}$ & SD & Ranking \\
\hline \multirow[t]{2}{*}{1} & \multirow{2}{*}{$\begin{array}{l}\text { Ensure that my family members are educated and } \\
\text { committed to precautionary measures and preven- } \\
\text { tion of the COVID-19. }\end{array}$} & K & 320 & 96 & o & \multirow[t]{2}{*}{2.77} & \multirow[t]{2}{*}{0.423} & \multirow[t]{2}{*}{7} \\
\hline & & $\%$ & $76.9 \%$ & $23.1 \%$ & o\% & & & \\
\hline \multirow[t]{2}{*}{2} & \multirow{2}{*}{$\begin{array}{l}\text { Make sure my family's reassurance of the Corona } \\
\text { crisis is strengthened. }\end{array}$} & K & 353 & 60 & 3 & \multirow[t]{2}{*}{2.84} & \multirow[t]{2}{*}{0.358} & \multirow[t]{2}{*}{4} \\
\hline & & $\%$ & $84.9 \%$ & $14.4 \%$ & $0.7 \%$ & & & \\
\hline \multirow[t]{2}{*}{3} & \multirow{2}{*}{$\begin{array}{l}\text { Make sure to select websites that provide informa- } \\
\text { tion. }\end{array}$} & $\mathrm{K}$ & 321 & 76 & 19 & \multirow[t]{2}{*}{2.73} & \multirow[t]{2}{*}{0.531} & \multirow[t]{2}{*}{10} \\
\hline & & $\%$ & $77.2 \%$ & $18.3 \%$ & $4.6 \%$ & & & \\
\hline \multirow[t]{2}{*}{4} & \multirow{2}{*}{$\begin{array}{l}\text { I am making sure that my sons discuss the State's } \\
\text { efforts for the COVID-19 crisis citizens. }\end{array}$} & K & 330 & 72 & 14 & \multirow[t]{2}{*}{2.76} & \multirow[t]{2}{*}{0.501} & \multirow[t]{2}{*}{9} \\
\hline & & $\%$ & $79 \cdot 3 \%$ & $17.3 \%$ & $3.4 \%$ & & & \\
\hline \multirow[t]{2}{*}{5} & \multirow{2}{*}{$\begin{array}{l}\text { I'm discussing with my sons the seriousness of the } \\
\text { rumour and its psychological impact during the } \\
\text { COVID-19 crisis }\end{array}$} & $\mathrm{K}$ & 356 & 49 & 11 & \multirow[t]{2}{*}{2.83} & \multirow[t]{2}{*}{0.441} & \multirow[t]{2}{*}{6} \\
\hline & & $\%$ & $85.6 \%$ & $11.8 \%$ & $2.6 \%$ & & & \\
\hline \multirow[t]{2}{*}{6} & \multirow{2}{*}{$\begin{array}{l}\text { Make sure I don't mention or convey rumours with } \\
\text { my sons in the COVID-19 crisis. }\end{array}$} & K & 291 & 119 & 6 & \multirow[t]{2}{*}{2.69} & \multirow[t]{2}{*}{0.459} & \multirow[t]{2}{*}{11} \\
\hline & & $\%$ & $70 \%$ & $28.6 \%$ & $1.4 \%$ & & & \\
\hline
\end{tabular}


Table 1: (Continued)

\begin{tabular}{|c|c|c|c|c|c|c|c|c|}
\hline $\begin{array}{l}\text { Sr. } \\
\text { No }\end{array}$ & Items & & Yes & Somewhat & No & $\mathbf{M}$ & SD & Ranking \\
\hline \multirow[t]{2}{*}{7} & \multirow{2}{*}{$\begin{array}{l}\text { Making my children aware of the danger of trans- } \\
\text { mitting information and the need to verify its origin } \\
\text { in the COVID-19 crisis }\end{array}$} & $\mathrm{K}$ & 267 & 144 & 5 & \multirow[t]{2}{*}{2.36} & \multirow[t]{2}{*}{0.508} & \multirow[t]{2}{*}{15} \\
\hline & & $\%$ & $64.2 \%$ & $34.6 \%$ & $1.2 \%$ & & & \\
\hline \multirow[t]{2}{*}{8} & \multirow{2}{*}{$\begin{array}{l}\text { I give my family proper information on the COV- } \\
\text { ID-19. }\end{array}$} & $\mathrm{K}$ & 328 & 80 & 8 & \multirow[t]{2}{*}{2.77} & \multirow[t]{2}{*}{0.465} & \multirow[t]{2}{*}{8} \\
\hline & & $\%$ & $78.8 \%$ & $19.2 \%$ & $1.9 \%$ & & & \\
\hline \multirow[t]{2}{*}{9} & \multirow{2}{*}{$\begin{array}{l}\text { Alert children not to accept unreasonable or logical } \\
\text { information about the COVID-19 crisis. }\end{array}$} & $\mathrm{K}$ & 379 & 35 & 2 & \multirow[t]{2}{*}{2.91} & \multirow[t]{2}{*}{0.308} & \multirow[t]{2}{*}{2} \\
\hline & & $\%$ & $91.1 \%$ & $8.4 \%$ & $0.5 \%$ & & & \\
\hline \multirow[t]{2}{*}{10} & \multirow{2}{*}{$\begin{array}{l}\text { Ensuring that my children are occupied with leisure } \\
\text { time to benefit and keep them out of the boredom } \\
\text { of the COVID-19 crisis }\end{array}$} & $\mathrm{K}$ & 322 & 56 & 38 & \multirow[t]{2}{*}{2.68} & \multirow[t]{2}{*}{0.633} & \multirow[t]{2}{*}{12} \\
\hline & & $\%$ & $77 \cdot 4 \%$ & $13.5 \%$ & $9.1 \%$ & & & \\
\hline \multirow[t]{2}{*}{11} & \multirow{2}{*}{$\begin{array}{l}\text { Instilling and promoting the patriotism of my sons } \\
\text { and repelling any rumour of the COVID-19 crisis }\end{array}$} & K & 379 & 34 & 3 & \multirow[t]{2}{*}{2.90} & \multirow[t]{2}{*}{0.319} & \multirow[t]{2}{*}{3} \\
\hline & & $\%$ & $91.1 \%$ & $8.2 \%$ & $0.7 \%$ & & & \\
\hline \multirow[t]{2}{*}{12} & \multirow{2}{*}{$\begin{array}{l}\text { Motivating my sons to start volunteering and serve } \\
\text { their community during the COVID-19 crisis }\end{array}$} & K & 290 & 91 & 35 & \multirow[t]{2}{*}{2.61} & \multirow[t]{2}{*}{0.638} & \multirow[t]{2}{*}{16} \\
\hline & & $\%$ & $69.7 \%$ & $21.9 \%$ & $8.4 \%$ & & & \\
\hline \multirow[t]{2}{*}{13} & \multirow{2}{*}{$\begin{array}{l}\text { I'm discussing with my sons the goals behind } \\
\text { spreading rumours and misinformation about the } \\
\text { COVID-19 crisis. }\end{array}$} & K & 293 & 106 & 17 & \multirow[t]{2}{*}{2.66} & \multirow[t]{2}{*}{0.553} & 14 \\
\hline & & $\%$ & $70.4 \%$ & $25 \cdot 5 \%$ & $4.1 \%$ & & & \\
\hline 14 & Raising awareness among children about the choice & $\mathrm{K}$ & 357 & 48 & 11 & 2.83 & 0.44 & 5 \\
\hline & $\begin{array}{l}\text { of social media sites and choosing the right content } \\
\text { at the time of the COVID-19 crisis }\end{array}$ & $\%$ & $85.8 \%$ & $11.5 \%$ & $2.6 \%$ & & & \\
\hline 15 & Develop national pride and prestige and attitudes in & $\mathrm{K}$ & 387 & 25 & 4 & 2.92 & 0.304 & 1 \\
\hline & the COVID-19 crisis & $\%$ & $93.0 \%$ & $6.1 \%$ & $1.0 \%$ & & & \\
\hline 16 & Raising awareness among my family members about & $\mathrm{K}$ & 285 & 123 & 8 & 2.67 & 0.511 & 13 \\
\hline & $\begin{array}{l}\text { the danger of rumour to the individual and society } \\
\text { and the purpose of its dissemination at the time of } \\
\text { the COVID-19 crisis }\end{array}$ & $\%$ & $68.5 \%$ & $29.6 \%$ & $1.9 \%$ & & & \\
\hline & Total & & & & & 2.76 & 0.244 & \\
\hline
\end{tabular}

reduce rumours during the Coronavirus pandemic crisis average (2.76 of 3), i.e., YES. More specifically, this axis comprises 16 items representing women's roles with the family in raising awareness to reduce rumours during the new coronavirus pandemic crisis, COVID-19. All came with means indicating Yes, i.e., approval, with averages ranging from 2.61 to 2.92 of 3 degrees.

"Develop national pride and prestige and attitudes in the Corona crisis," ranked first, with an average of 2.92 , i.e., yes. With a very low standard deviation of 0.304 , it showed no difference in the study sample's views on this role, and $93 \%$ of the study sample supported it, only $1 \%$ rejected it, and $6 \%$ indicated somewhat. However, item No. 9, "Alert children not to accept unreasonable or logical information about the Corona crisis," ranked second, with an average of 2.91, i.e., yes, and the rest of this axis has a variety of items, all of which refer to yes. "Motivating my sons to start volunteering and serve their community during the Corona crisis," ranked $16^{\text {th }}$ and last in axis items with an average of (2.61), i.e., yes, but with a standard deviation of 0.638 to show differing views of the study sample on this item, as well as $69.7 \%$ of the study sample supported it and only $8.4 \%$ rejected it, while $21.9 \%$ indicated somewhat.

Table 2: Means, Standard Deviations, Percentage and ranking on the Dimensions of the first field (Women's role with society in raising awareness to reduce rumours during the crisis of COVID-19 pandemic)

\begin{tabular}{|c|c|c|c|c|c|c|c|c|}
\hline N. & Items & & Yes & Somewhat & No & M & SD & Ranking \\
\hline \multirow{2}{*}{1} & Explain the importance of the blessings of & K & 368 & 16 & 2 & \multirow{2}{*}{2.95} & \multirow{2}{*}{0.236} & \multirow{2}{*}{2} \\
\hline & security and food during the Corona crisis. & $\%$ & $95.7 \%$ & $3.8 \%$ & $0.5 \%$ & & & \\
\hline \multirow{2}{*}{2} & Pride and prestige in the efforts of the State & K & 402 & 11 & 3 & \multirow{2}{*}{2.96} & \multirow{2}{*}{0.232} & \multirow{2}{*}{1} \\
\hline & in what it offers citizens in the Corona crisis & $\%$ & $96.6 \%$ & $2.6 \%$ & $0.7 \%$ & & & \\
\hline
\end{tabular}


Table 2: (Continued)

\begin{tabular}{|c|c|c|c|c|c|c|c|c|}
\hline N. & Items & & Yes & Somewhat & No & $\mathbf{M}$ & SD & Ranking \\
\hline 3 & $\begin{array}{l}\text { Clarifying the nation's importance and } \\
\text { strengthening the spirit of belonging and the } \\
\text { gravity of the rumour in the Corona crisis }\end{array}$ & $\begin{array}{l}\mathrm{K} \\
\%\end{array}$ & $\begin{array}{c}301 \\
72.4 \%\end{array}$ & $\begin{array}{c}113 \\
27.2 \%\end{array}$ & $\begin{array}{c}2 \\
0.5 \%\end{array}$ & 2.72 & 0.461 & 7 \\
\hline 4 & $\begin{array}{l}\text { Clarify the role of citizens to face rumours } \\
\text { during Corona crisis }\end{array}$ & $\begin{array}{l}\mathrm{K} \\
\%\end{array}$ & $\begin{array}{c}311 \\
74.8 \%\end{array}$ & $\begin{array}{c}102 \\
24 \cdot 5 \%\end{array}$ & $\begin{array}{c}3 \\
0.7 \%\end{array}$ & 2.74 & 0.455 & 6 \\
\hline 5 & $\begin{array}{l}\text { Promoting a culture of confidence and trust } \\
\text { in the State's efforts in the Corona crisis }\end{array}$ & $\begin{array}{l}\mathrm{K} \\
\%\end{array}$ & $\begin{array}{c}377 \\
90.6 \%\end{array}$ & $\begin{array}{c}36 \\
8.7 \%\end{array}$ & $\begin{array}{c}3 \\
0.7 \%\end{array}$ & 2.90 & 0.325 & 3 \\
\hline 6 & $\begin{array}{l}\text { Reducing the transmission of any rumours } \\
\text { of the Corona crisis without checking the } \\
\text { source }\end{array}$ & $\begin{array}{l}\mathrm{K} \\
\%\end{array}$ & $\begin{array}{c}279 \\
67.1 \%\end{array}$ & $\begin{array}{c}131 \\
31.5 \%\end{array}$ & $\begin{array}{c}6 \\
1.4 \%\end{array}$ & 2.66 & 0.505 & 9 \\
\hline 7 & $\begin{array}{l}\text { Clarify and discuss the seriousness of } \\
\text { rumours and their psychological impact on } \\
\text { society in the Corona crisis }\end{array}$ & $\begin{array}{l}\mathrm{K} \\
\%\end{array}$ & $\begin{array}{c}352 \\
84.6 \%\end{array}$ & $\begin{array}{c}63 \\
15.1 \%\end{array}$ & $0.2 \%$ & 2.84 & 0.370 & 4 \\
\hline 8 & $\begin{array}{l}\text { Contribute to raising awareness about the } \\
\text { goals behind spreading rumours and misin- } \\
\text { formation about the Corona crisis }\end{array}$ & $\begin{array}{l}\mathrm{K} \\
\%\end{array}$ & $\begin{array}{c}334 \\
80.3 \%\end{array}$ & $\begin{array}{c}42 \\
10.1 \%\end{array}$ & $\begin{array}{c}40 \\
9.6 \%\end{array}$ & 2.71 & 0.633 & 8 \\
\hline 9 & $\begin{array}{l}\text { Contribute to discuss the seriousness of } \\
\text { rumours on the individual and society in the } \\
\text { Corona crisis }\end{array}$ & $\begin{array}{l}\mathrm{K} \\
\%\end{array}$ & $\begin{array}{c}328 \\
78.8 \%\end{array}$ & $\begin{array}{c}80 \\
19.2 \%\end{array}$ & $\begin{array}{c}8 \\
1.9 \%\end{array}$ & 2.77 & 0.465 & 5 \\
\hline & Total & & & & & 2.81 & 0.228 & \\
\hline
\end{tabular}

According to the above table, it appears that the sample of female students' mothers at Princess Noura University approved the roles offered to women with society in raising awareness to reduce rumours during the crisis of the Coronavirus pandemic, with an average of (2.81 out of 3$)$, i.e., yes. More specifically, this axis comprises nine items representing women's roles in society. All came with means indicating Yes, i.e., approval, with averages ranging from 2.66 to 2.96 of 3 degrees. "Pride and prestige in the efforts of the State in what it offers citizens in the Corona crisis" ranked first, with an average of 2.96, i.e., yes. With a very low standard deviation of 0.23 , it showed no difference in the study sample's views on this role, and $96.6 \%$ of the study sample supported it, only $0.7 \%$ rejected it, and $2.6 \%$ indicated somewhat. However, item No. 1, "Explain the importance of the blessings of security and food during the Corona crisis," ranked second, with an average of 2.95 , i.e., yes, and the rest of this axis has a variety of items, all of which refer to yes." Reducing the transmission of any rumours of the Corona crisis without checking the source," ranked $9^{\text {th }}$ and last in axis items with an average of (2.66), i.e., yes, but with a standard deviation of 0.505 ; to show differing views of the study sample on this item, as well as $67.1 \%$ of the study sample, supported it and only $1.4 \%$ rejected it, while $31.5 \%$ indicated somewhat.

Table 3: Means, Standard Deviations, Percentage and ranking on the Dimensions of the first field (Proposals and mechanisms to activate the role of women in raising awareness to reduce rumours during the crisis COVID-19 pandemic)

\begin{tabular}{|c|c|c|c|c|c|c|c|c|}
\hline $\mathbf{N}$ & Items & & Yes & Somewhat & No & $\mathbf{M}$ & SD & Ranking \\
\hline 1 & $\begin{array}{l}\text { Clarify the role of women in the media } \\
\text { and social media platforms; to contrib- } \\
\text { ute to the psychological balance and } \\
\text { reassurance of their family and com- } \\
\text { munity and reducing rumours in the } \\
\text { Corona crisis }\end{array}$ & $\begin{array}{l}\mathrm{K} \\
\%\end{array}$ & $\begin{array}{l}283 \\
68.0 \%\end{array}$ & $\begin{array}{l}125 \\
30.0 \%\end{array}$ & $\begin{array}{l}8 \\
1.9 \%\end{array}$ & 2.66 & 0.513 & 7 \\
\hline 2 & $\begin{array}{l}\text { Organize training courses for women in } \\
\text { family and community crisis manage- } \\
\text { ment through e-learning }\end{array}$ & $\begin{array}{l}\mathrm{K} \\
\%\end{array}$ & $\begin{array}{l}290 \\
69 \cdot 7 \%\end{array}$ & $\begin{array}{l}105 \\
25.2 \%\end{array}$ & $5.0 \%$ & 2.65 & 0.575 & 8 \\
\hline 3 & $\begin{array}{l}\text { Disseminate awareness messages about } \\
\text { the dangers of rumour during crises for } \\
\text { women }\end{array}$ & $\begin{array}{l}\mathrm{K} \\
\%\end{array}$ & $\begin{array}{l}224 \\
53.8 \%\end{array}$ & $\begin{array}{l}177 \\
42.5 \%\end{array}$ & $\begin{array}{l}15 \\
3.6 \%\end{array}$ & 2.50 & 0.567 & 11 \\
\hline
\end{tabular}


Table 3: (Continued)

\begin{tabular}{|c|c|c|c|c|c|c|c|c|}
\hline $\mathbf{N}$ & Items & & Yes & Somewhat & No & $\mathbf{M}$ & SD & Ranking \\
\hline 4 & $\begin{array}{l}\text { Hold ongoing interactive sessions to } \\
\text { sensitize women to the dangers of the } \\
\text { transmission, circulation of rumours, } \\
\text { and their psychological impact on the } \\
\text { individual and society }\end{array}$ & $\begin{array}{l}\mathrm{K} \\
\%\end{array}$ & $\begin{array}{l}235 \\
56.5 \%\end{array}$ & $\begin{array}{l}107 \\
25 \cdot 7 \%\end{array}$ & $\begin{array}{l}74 \\
17.8 \%\end{array}$ & 2.39 & 0.771 & 12 \\
\hline 5 & $\begin{array}{l}\text { Raising women's awareness through } \\
\text { the various media about their role in } \\
\text { their families and society; to reduce the } \\
\text { spread of rumours }\end{array}$ & $\begin{array}{l}\mathrm{K} \\
\%\end{array}$ & $\begin{array}{l}3 \cdot 9 \\
74 \cdot 3 \%\end{array}$ & $\begin{array}{l}88 \\
21.2 \%\end{array}$ & $\begin{array}{l}19 \\
4.6 \%\end{array}$ & 2.70 & 0.551 & 6 \\
\hline 6 & $\begin{array}{l}\text { Urging women through various media } \\
\text { to develop their knowledge capacities in } \\
\text { crisis management }\end{array}$ & $\begin{array}{l}\mathrm{K} \\
\%\end{array}$ & $\begin{array}{l}261 \\
62.7 \%\end{array}$ & $\begin{array}{l}142 \\
34.1 \%\end{array}$ & $\begin{array}{l}13 \\
3.1 \%\end{array}$ & 2.60 & 0.551 & 10 \\
\hline 7 & $\begin{array}{l}\text { Includetheories of crisis in school cur- } \\
\text { ricula, and learn how to apply them at } \\
\text { the educational level }\end{array}$ & $\begin{array}{l}\mathrm{K} \\
\%\end{array}$ & $\begin{array}{l}317 \\
76.2 \%\end{array}$ & $\begin{array}{l}87 \\
20.9 \%\end{array}$ & $\begin{array}{l}12 \\
2.9 \%\end{array}$ & 2.73 & 0.504 & 4 \\
\hline 8 & $\begin{array}{l}\text { Publish seminars and conferences ex- } \\
\text { plaining the threat of rumour and how } \\
\text { to prevent it through e-learning }\end{array}$ & $\begin{array}{l}\mathrm{K} \\
\%\end{array}$ & $\begin{array}{l}269 \\
64.7 \%\end{array}$ & $\begin{array}{l}132 \\
31.7 \%\end{array}$ & $\begin{array}{l}15 \\
3.6 \%\end{array}$ & 2.61 & 0.557 & 9 \\
\hline 9 & $\begin{array}{l}\text { Legal awareness of women through the } \\
\text { statement of penalties for the dissemi- } \\
\text { nation and circulation of rumours }\end{array}$ & $\begin{array}{l}\mathrm{K} \\
\%\end{array}$ & $\begin{array}{l}366 \\
88.0 \%\end{array}$ & $\begin{array}{l}36 \\
8.7 \%\end{array}$ & $\begin{array}{l}14 \\
3.3 \%\end{array}$ & 2.85 & 0.445 & 1 \\
\hline 10 & $\begin{array}{l}\text { Disseminate awareness through the } \\
\text { various media illustrates the danger of } \\
\text { rumour during the crisis }\end{array}$ & $\begin{array}{l}\mathrm{K} \\
\%\end{array}$ & $\begin{array}{l}311 \\
74.8 \%\end{array}$ & $\begin{array}{l}95 \\
22.8 \%\end{array}$ & $\begin{array}{l}10 \\
2.4 \%\end{array}$ & 2.72 & 0.499 & 5 \\
\hline 11 & $\begin{array}{l}\text { Activate the role of women in the educa- } \\
\text { tion sector to raise awareness against the } \\
\text { threat of rumour, especially in crises }\end{array}$ & $\begin{array}{l}\mathrm{K} \\
\%\end{array}$ & $\begin{array}{l}361 \\
86.8 \%\end{array}$ & $\begin{array}{l}37 \\
8.9 \%\end{array}$ & $\begin{array}{l}18 \\
4 \cdot 3 \%\end{array}$ & 2.82 & 0.481 & 2 \\
\hline 12 & $\begin{array}{l}\text { Promote women's role in the health } \\
\text { sector to participate in the statement } \\
\text { of rumours and their psychological and } \\
\text { health impact on people, especially in } \\
\text { times of crisis }\end{array}$ & $\begin{array}{l}\mathrm{K} \\
\%\end{array}$ & $\begin{array}{l}339 \\
81.5 \%\end{array}$ & $\begin{array}{l}61 \\
14.7 \%\end{array}$ & $\begin{array}{l}16 \\
3.8 \%\end{array}$ & 2.78 & 0.501 & 3 \\
\hline & Total & & & & & 2.67 & 0.376 & \\
\hline
\end{tabular}

Based on the above table, it appears that the sample of female students' mothers at Princess Nora University approved proposals and mechanisms to activate women's role in raising awareness to reduce rumours during the Corona pandemic crisis, on average (2.67 of 3), i.e., YES. More specifically, this axis comprises 12 items representing a set of proposals and mechanisms. All came with means indicating Yes, i.e., approval, with averages ranging from 2.39 to 2.85 of 3 degrees. Item No. 9, "Legal awareness of women through the statement of penalties for the dissemination and circulation of rumours," ranked first, with an average of 2.85 , i.e., yes. With a very low standard deviation of 0.445 , it showed no difference in the study sample's views on this role, and $88 \%$ of the study sample supported it, only $3.4 \%$ rejected it, and $8.7 \%$ indicated somewhat. However, item No. 11, "Activate the role of women in the education sector to raise awareness against the threat of rumour, especially in crises," ranked second, with an average of 2.82 , i.e., yes, and the rest of this axis has a variety of items, all of which refer to yes. "Hold ongoing interactive sessions to sensitize women to the dangers of the transmission, circulation of rumours, and their psychological impact on the individual and society," ranked $12^{\text {th }}$ and last in axis items with an average of (2.39), i.e., yes, but with a standard deviation of 0.771 to show differing views of the study sample on this item, as well as $56.5 \%$ of the study sample supported it and $17.8 \%$ rejected it, while $25.7 \%$ indicated somewhat. 


\section{DISCUSSION}

This study aimed to identify women's role in raising awareness to reduce rumours during the COVID-19 crisis and present some proposals and mechanisms to activate their role. According to the first question results, participants demonstrated their strong agreement on women's role with the family in raising awareness to reduce rumours during the new coronavirus crisis, COVID-19. More specifically, its role in developing national pride and prestige and attitudes in the Corona crisis has been approved and alert children not to accept unreasonable or logical information about the Corona crisis. In addition to instil and promote my sons' patriotism and repel any rumour of the Corona crisis. Further, educate their children about the choice of social media sites and appropriate content in the Corona crisis or discuss the rumour's seriousness and its psychological impact during the Corona crisis. Moreover, they are concerned with educating and committing family members to precautionary measures and preventing Coronavirus or providing correct Coronavirus information. Thus, discuss the State's efforts that provide citizens in the Corona crisis with their children. Select websites that provide information about the Corona crisis, and not mention or convey rumours with their children in the Corona crisis. Additionally, ensure that leisure time is occupied for the benefit of her children and keep them away from the Corona crisis and make her family members aware of the danger of rumours on the individual and society and the purpose of its dissemination at the time of the Corona crisis. The results also confirmed that one of the women's roles was to discuss their children's goals behind the dissemination of rumours and misinformation about the Corona crisis, make them aware of the danger of transmitting information and the need to verify its origin and motivate them to take part in volunteer work and serve their society during the crisis. Those findings are consistent with many previous studies, such as. ${ }^{27,32,33}$

According to the second question results, participants demonstrated their strong agreement on women's role with the society in raising awareness to reduce rumours during the new coronavirus crisis. More specifically, her role in the development of pride and prestige in the State's efforts in what it offers citizens in the Corona crisis, explain the importance of the blessings of security and food during the Corona crisis and promote a culture of confidence and trust in the State's efforts in the Corona crisis. She also clarifies and discusses the seriousness of rumours and their psychological impact on society in the Corona crisis. Furthermore, her contribution to discussing the severity of rumours on the individual and society in the Corona crisis, clarifying citizens' role to face rumours, and strengthening the spirit of belonging and the rumour's gravity in the Corona crisis during the Corona crisis. Results also confirmed her contribution to raising aware- ness about the goals behind spreading rumours and misinformation about the Corona crisis. In addition to reducing the transmission of any rumours of the Corona crisis without checking the source. Those findings are consistent with many previous studies, such as. ${ }^{34-36}$ Ultimately, the study results showed participants' agreement on a set of proposals and mechanisms to activate women's role in developing awareness to reduce rumours during the new Coronavirus crisis, COVID-19. More specifically, legal understanding of women through the statement of penalties for disseminating and circulating rumours. In addition to activating the role of women in the education sector to raise awareness against the threat of rumour, especially in crises, and promote their role in the health sector to participate in the statement of rumours and their psychological and health impact on people, especially in times of crisis. The results also confirmed that it was essential to include crisis theories in school curricula, learn how to apply them at the educational level, and disseminate awareness through the various media that illustrate the danger of rumour during the crisis.

It also emphasizes the importance of raising women's awareness through the various media about their role in their families and society; to reduce the spread of rumours, and clarifying their role in the media and social media platforms; to contribute to the psychological balance and reassurance of their family and community and reducing rumours in the Corona crisis. In addition to organizing training courses for women in family and community crisis management through E-learning. Thus, urging women through various media to develop their knowledge capacities in crisis management, and publish seminars and conferences explaining the threat of rumour and how to prevent it through e-learning. Moreover, hold ongoing interactive sessions to sensitize women to the dangers of the transmission, circulation of rumours, and their psychological impact on the individual and society.

\section{CONCLUSION}

The paper reviewed the results of women's role in raising awareness of rumours during the COVID-19 crisis. These measurements were applied to a sample of community members in Riyadh, Saudi Arabia. This research's main contribution is that it provides a deep understanding of Saudi women's role in raising awareness of rumours during the COVID- 9 crisis. Besides, some proposals have been made to activate Saudi women's role in raising awareness of rumours in crises, particularly the COVID-19 crisis. In particular, this issue has not received sufficient attention in Arab society, especially in Saudi Arabia. Therefore, this study attempted to shed light on women's role in raising awareness of rumours during the COVID-19 crisis. In addition to the need for the Saudi Government to look at this vital issue with greater depth and attention and give full support to Saudi 
women to help them fulfil their role in raising awareness of rumours in crises. One of the most severe crises we are now experiencing, the COVID-19 crisis. That's through: Expanding the organization of lectures, seminars, and meetings at universities, schools, and awareness centres for debate to demonstrate the danger of rumour and its spread. Study and improve family conditions by national authorities to create a risk-conscious environment such as rumours. Moreover, through socialization processes, all society institutions - family, school, and community - should raise awareness against rumours. In addition, launch a national initiative to raise awareness of rumours in society and at all levels, and intensify all institutions of social forces through conferences, seminars, and courses. Further, establish an integrated information Center overseen by a government body to provide information, correct rumours, and reduce it. School curricula should also be taken into account, and the dangers of rumours and their impact on the individual and society should be incorporated. Eventually, legislate and apply penalties for rumours on the individual, community, and the State.

Funding: We are thankful for funding from the Center for Promising Research in Social Research and Women's in Princess Nourah bint Abdulrahman University in the Kingdom of Saudi Arabia in 2020.

\section{ACKNOWLEDGEMENTS}

We acknowledgements the Deanship of Scientific Research and Center for Promising Research in Social Research and Women's Princess Noura bint Abdulrahman University in the Kingdom of Saudi Arabia for its support and facilitation of the procedures for implementing the study. We also acknowledgements the mothers for whom the study tools were applied, and help them achieve the goals of the study.

Conflicts of Interest: No conflicts of interest.

Informed consent: Verbal informed consent was obtained before the collectionof data.

\section{Authors' contributions:}

Loulouh Albrkan; Designed the study, funding acquisition, protocol writing and manuscript preparation.

Hend Al-Shahrani; Protocol writing, manuscript review, formal analysis and guided research work.

\section{REFERENCES}

1. Ramasamy K, Jayakumar S. The Trend of COVID-19 at Bengaluru: Prediction to Continue the Better Epidemic Management. Int J curr Res Rev. 2020;12(13):56-60.

2. Vaishnavi P, Ramkumar S. COVID-19: Survey on Awareness Level and Psychological Status During the Outbreak. Int J Curr Res Rev. 2020;12(18):85.
3. Arafa A, Mohammed Z, Mahmoud O, Elshazley M, Ewis A. Depressed, anxious, and stressed: What have healthcare workers on the frontlines in Egypt and Saudi Arabia experienced during the COVID-19 pandemic? J Affect Disord 2021;278:365-71.

4. Mitra M, Basu M. Perspectives of Medical Students on Medical Education Services during the COVID-19 Pandemic in India. Int J Curr Res Rev. 2020;12(15):26-30.

5. World Health Organization. Coronavirus disease 2019 (COVID-19): situation report, 82. 2020.

6. Sood S. Psychological effects of the Coronavirus disease-2019 pandemic. Res Humanit Med Educ. 2020;7(11):23-26.

7. Hammad MA, Alqarni TM. Psychosocial effects of social media on the Saudi society during the Coronavirus Disease 2019 pandemic: A cross-sectional study. Plos one. 2021;16(3):1-13.

8. Hassounah M, Raheel H, Alhefzi M. Digital response during the COVID-19 pandemic in Saudi Arabia. J Med Internet Res. 2020;22(9):1-14.

9. Saji JA, Babu BP, Sebastian SR. Social influence of COVID-19: An observational study on the social impact of post-COVID-19 lockdown on everyday life in Kerala from a community perspective. J Edu Health Promot. 2020;9(1):1-4.

10. Gathiya N, Kumar S. Psychosocial implication of quarantine and lockdown during COVID-19 pandemic in India. J Edu Health Promot. 2020;9(1):1-5.

11. Gupta A, Jagzape A, Kumar M. Social media effects among freshman medical students during COVID-19 lock-down: An online mixed research. J Edu Health Promot. 2021;10(1):1-6.

12. DiFonzo N, Bordia P. Rumor, gossip and urban legends. Diogenes. 2007;54(1):19-35.

13. Marett K, Joshi KD. The decision to share information and rumours: Examining the role of motivation in an online discussion forum. Commun AIS. 2009;24(1):47-68.

14. Kouzy R, Abi Jaoude J, Kraitem A, El Alam MB, Karam B, Adib $\mathrm{E}$, et al. Coronavirus goes viral: quantifying the COVID-19 misinformation epidemic on Twitter. Cureus. 2020;12(3): 1-9.

15. Pennycook G, McPhetres J, Zhang Y, Lu JG, Rand DG. Fighting COVID-19 misinformation on social media: Experimental evidence for a scalable accuracy-nudge intervention. Psychol Sci. 2020;31(7):770-80.

16. Sallam M, Dababseh D, Yaseen A, Al-Haidar A, Taim D, Eid $\mathrm{H}$, et al. COVID-19 misinformation: Mere harmless delusions or much more? Knowledge and attitude cross-sectional study among the general public residing in Jordan. PloS one. 2020;15(12):e0243264.

17. Radwan E, Radwan A, Radwan W. The role of social media in spreading panic among primary and secondary school students during the COVID-19 pandemic: An online questionnaire study from the Gaza Strip, Palestine. Heliyon. 2020;6(12):e05807.

18. AlHumaid J, Ali S, Farooq I. The psychological effects of the COVID-19 pandemic and coping with them in Saudi Arabia. Psychol Trauma. 2020;12(5):505-507.

19. Atlani-Duault L, Ward JK, Roy M, Morin C, Wilson A. Tracking online heroisation and blame in epidemics. Lancet Public Health. 2020;5(3):e137-e8.

20. Shankari SB, Rani L, Brundha JS. Knowledge and Awareness on Role of Social Media in Managing COVID-19 Among General Population-A Questionnaire Study. Int J Curr Res Rev. 2020;12(19):197-202.

21. Depoux A, Martin S, Karafillakis E, Preet R, Wilder-Smith A, Larson $\mathrm{H}$. The pandemic of social media panic travels faster than the COVID-19 outbreak. J Travel Med. 2020;24:36-44.

22. Guan X, Li X. A cross-cultural examination of family communication patterns, parent-child closeness, and conflict styles in the United States, China, and Saudi Arabia. J Fam Comm. 2017;17(3):223-37. 
23. Lirio P, Lituchy TR, Monserrat SI, Olivas-Lujan MR, Duffy JA, Fox S, et al. Exploring career-life success and family social support of successful women in Canada, Argentina and Mexico. Career Dev Int. 2007;12(1): 28-50.

24. Kavya C, Manjunatha S. A Sociological Study on The Role of Gram Panchayats in Women Empowerment in Karnataka State. Int J Curr Res 2015;7(23):54-58.

25. Beekle A, McCabe C. Awareness and determinants of family planning practice in Jimma, Ethiopia. Int Nurs Rev. 2006;53(4):269-76.

26. Borah K, Bhuyan K, Bhuyan D. Alcohol Use Disorder in Adolescents from Network Theory Perspective. Int J Curr Res Rev. 2019;11(13):1-6.

27. Liau AK, Khoo A, Ang PH. Parental awareness and monitoring of adolescent Internet use. Curr Psychol. 2008;27(4):217-233.

28. Spielberger C. Encyclopedia of applied psychology: Academic press; 2004.

29. Lopata HZ. Role theory. Social roles and social institutions: Essays in honour of Rose Laub Coser. 1991:1-11.

30. AL-Hazmi MA, Hammad MA, AL-Shahrani HF. Obstacles of Saudi Woman Work in the Mixed Environment: A Field Study. Int Educ Stud. 2017;10(8):128-144.
31. Shams B, Golshiri P, Najimi A. The evaluation of mothers' participation project in children's growth and development process: using the CIPP evaluation model. J Health Promot Educ. 2013;2:1-12.

32. Crede J, Wirthwein L, McElvany N, Steinmayr R. Adolescents' academic achievement and life satisfaction: The role of parents' education. Front Psychol 2015;6:52:1-8.

33. Sharma N, Vaish H. Impact of COVID-19 on mental health and physical load on women professionals: an online cross-sectional survey. Health Care Women Int. 2020:1-18.

34. Ballarotto G, Volpi B, Marzilli E, Tambelli R. Adolescent Internet abuse: A study on the role of attachment to parents and peers in a large community sample. BioMed Res Int. 2018;2018.

35. Procentese F, Gatti F, Di Napoli I. Families and social media use The role of parents' perceptions about social media impact on family systems in the relationship between family collective efficacy and open communication. Int J Environ. Res Public Health. 2019;16(24):1-11.

36. Richards MH, Gitelson IB, Petersen AC, Hurtig AL. Adolescent personality in girls and boys: The role of mothers and fathers. Psychol Women Q. 1991;15(1):65-81. 